\title{
Rabindranath Tagore's Home and the World [Ghare Bhaire] : A Gripping Portrayal of Swadeshi Movement
}

\author{
P.V. Laxmiprasad \\ Satavahana University \\ Karimnagar, Telangana, India \\ laxmiprasad.puram@gmail.com
}

\begin{abstract}
Tagore's novel Ghare Bhaire has historical significance when we look at it from nationalistic perspective. The Swadeshi movement predominantly began with the partition of Bengal by the Viceroy of India, Lord Curzon in 1905 and continued up to 1911. This was precisely the most successful of the Pre- Gandhian movements. MK Gandhi strategically focused on Swadeshi who described it as the Soul of Swaraj (Self-rule). The movement was officially announced on 7 August, 1905 at the famous Calcutta Town Hall, in Bengal. Later, this was used to boycott all the British goods in the country. The spirit of the movement was to use goods produced in India and burning of British-made goods. Swadeshi movement paved the way to the successive movements such as Satyagraha movement and Non-Cooperation movement. Written against the backdrop of the partition of Bengal by the British in 1905, Home and the World (Ghare Bhaire) by Rabindranath Tagore, the Nobel Laureate, is a telling portrayal of the chasms inherent in the nationalist movement. Any movement by people is particularly interesting and a movement such as Swadeshi movement holds special significance in the history of Indian Freedom Struggle. Swadeshi was a clarion call to rebel against the imported goods. In the words of Anita Desai, the
\end{abstract}


noted Indo-English novelist, "Home and the World" has the complexity and tragic dimensions of Tagore's own time and ours". Readers are reminded that Tagore protested the Jallianwallah Bagh massacres and rejected the knighthood honour. He set himself an example by leading the country against the oppressions. His patriotism finds literary expression in the novel "Ghare Bhaire" Where Swadeshi Movement dominates the collection.

Keyword: Nationalism, Patriotism, Swadeshi, Partition, Boycott

In the introduction to 'Ghare Bhaire', Swagato Ganguly writes that "The Vande Mataram" (Hail Mother Land) slogan that is strewn through "Home and the world" is the name of a hymn the first appeared in Anandmath, and subsequently became the marseillaise of the Indian nationalist Movement (X-Introduction to Ghare Bhaire)

Swadeshi Agitators organized boycotts of foreign goods, chiefly textiles, and made occasional bonfires of them. Nikhilesh, the protagonist, observes that "Sobriety needs to manifest itself" Today all our needs are linked to those of the world". It resonates with the swadeshi versus globalization debates in the country today. At this point, the wave of swadeshi swept through the country side. The young boys who went to school or college in Calcutta, came back for the holidays. They appointed sandip as their chief and wholeheartedly lent themselves to the task of spreading the swadeshi message. One of the boys said, "You will have to ban foreign threads and clothes from the suksayar market" (Home and the world - 107)

At this, Chandanath Babu overrode what others were saying. He remarked that, "The country is not just this land and soil, it is also the people. Have you ever bothered to spare these people a second glance? Today, suddenly you have woken up to the fact that you must decide what they'd eat and what they'd wear. Why should we tolerate that and why should we let them 
tolerate that and why should we let them tolerate that? They replied, "But we ourselves have taken to indigenous salt, sugar and cloth.” (Home and the World-107-108).

There were heated dialogues in the novel among the students and ex-professors who argued for and against the Swadeshi Movement. But, Chandranath Babu in dissident tone and rebellious voice said "Moreover even those who have taken the vow seem more intent on causing havoc. You would like to force the uninitiated to buy the thread, weave the cloth and also buy the fabric. By what means? By force and the use of the Zamindar's henchmen and their lathis. In other words, the vow is yours, but the ordinary people are the ones who will fast and you will celebrate that fasting" (Home and the world-109) one finds that there are supporters, agitators and rebels for and against the swadeshi movement. There were people who backed and rebelled. Dissidence and distrust made them rebellious. Endless debates continued among the students of different disciplines. It was a typical zamindari swadeshi movement that Tagore largely referred to in the novel.

An account of Zarmindari's aggression (Harish Kund) and subsequent fining of panchu is found in his outbursts: "he sold foreign cloth. He went to the Zamindar and fell at his feet saying that he had bought this cloth with money taken on loan and once these were sold off, he would never do such a thing again. The Zamindar said, "Impossible". Burn the cloth in front of me and only then will I let you go". Panchu couldn't take it. He shouted, "I cannot afford it, I am poor; You have enough. Why don't you buy the cloth and then burn it? "At this, the Zamindar flared up and said. "You bastard, your tongue wags too much-give him the shoe". One round of humiliation followed and then he was fined a hundred rupees". These are the kind that follow sandip around, shouting Vande Mataram” (Home and the World - 110) 
While Nikhilesh's nationalism is idiosyncratically indigenous, Sandip's nationalism is of foreign import. In the comments of Swagato Ganguly, "Sandip's nationalism is a foreign import, and he refers to west sex manuals while pursuing Bimala. Tagore underlines Sandip's duplicity as a swadeshi leader by having Nikhilesh point out that he keeps three shelves full of western medicines in his living room, even as he claims to Bimala that he relies exclusively on indigenous Ayurvedic medicine in treating his ailments. But, Nikhilesh and Chandranath would have it, then there is a certain sort of nationalism here, an implicit brawn man's burden. And indeed, Nikhilesh cultivates his own brand of Swadeshi in the novel : he writes with a quill, reads by lamplight, keeps indigenously manufactured furniture in his living room, and sponsors swadeshi enterprises on his estate, But his version of Swadeshi is marked by sobriety and selfcontrol, and he draws the line at coercising those who don't wish to participate. His antiimperialist strategy is not so much to oust the foreign ruler, as to ignore his existence" (Swagato Ganguly - Introduction to Home and the World - 12)

What the readers particularly find in Nikhilesh is that he dresses his wife in western fashions, and hires a British tutor to educate her. Bimala's dress, her demeanor and her English tutor have been considered 'transgressive' by the rest of the family members. Sandip's duplicity of nationalism is how Tagore describes : "The truth we need to formulate. Many lies are needed to make the truth just as many illusions are needed to make the world. Those who have come into this world solely to create, they do not accept truth, they formulate it”.

(Home and the world - 111)

Bimala's comments on Swadeshi Movement are note-worthy here in the context of growing interest for self-made goods. "Listen, in all of Bengal our market is the only one stocking foreign cloth; does it look good? "I asked, "What will be the best thing to do? Why 
don't you tell them to throw those-things away? But those things do not belong to me" But the market is yours". Why can't they buy it, but if they buy indigenous goods? I'd be happy if they do buy it, but if they don't What? How can they dare to? I don't have much time. What is the point of arguing over this? I cannot bring over this? I cannot bring myself to exploit people". "The exploitation is not for your gain, it's for the sake of the country" (Home and the world 114-115)

There were real differences between Sandip and Nikhilesh about patriotism. But the words that Bimala spoke in the name of movement were coming from Sandip's mouth and not from a greater idea. Bimala followed sandip in every spoken word. Eventually, Nikhilesh felt that he would have to fight with those shadows that lay emaciated, tired and blinded by ignorance on the one hand, and on the other hand that had thrived on the blood of the poor. Realization dawns on Nikhilesh : "Today I felt I shall be a winner. I stand on the straight road; I can see everything clearly. I have been freed and I have also freed - my salvation lies where my world is. Oh truth, save me, help me. Don't let me go back to that fake world of illusions and artifice". (Home and the world - 117)

While critically evaluating the drawing-rooms of both Nikhilesh and Sandip, Swagato Ganguly rightly observes: "In terms of the cartography of the Swadeshi self of the house hold, particularly its inner chambers where the women reside, is the bastion of tradition and expresses one's cultural core, whereas one ventures outside to meet the world. The drawing-room, as Sandip points out, is an "ambiguous space, neither indoors nor outdoors". It is where home meets the world. Nikhilesh has important European guests over, but he makes it a point to decorate his drawing room with Swadeshi objects, preferring a common brass pot over an expensive European vase. When queried by Bimala about his choice, Nikhilesh tells her "my 
brass pot is as un-self conscious as these flowers. But yours foreign flower vase doggedly lets you know that it is vase". (Swagato Ganguly - Introduction to Home and the world - 14-15) The Swadeshi formula implies that the indigenous is substituted herewith the homely and the organic, while the foreign vase represents mechanical artifice.

To conclude the paper, I reckon that Rabindranath Tagore thoroughly deals with the complexities and tragic dimensions of his own time in Home and the World (Ghare Bhaire). As he was passionately attracted by the Swadeshi movement in the days of freedom struggle, he presented those burning issues from his tripolar characters like Nikhilesh, Sandip and Bimala. While Sandip decidedly looks at the west, the other Nikhilesh deals with the Swadeshi from the Zamindar aristocratic family background. Of course, there were incidents for and against the movement. There was a bulk of support and rebellion. Yet, the events portrayed that Home meets the world towards the end. Truly, the novel is a mirror of its age so far as the concerns and the relevancies are considered. 


\section{Works Cited}

Tagore, Rabindranath. Home and the World (Ghare Bhaire) Tra. Sreejata Guha, New Delhi :Penguin Books India. 2005 Print.

Ganguly, Swagato. "Introduction”. Home and the World. ( Ghare Bhaire). 12-15. Print. 